\title{
プロテオミクスを用いた細胞内リン酸化動態の計測
}

\author{
石濱 泰, ${ }^{*}, a$ 今見考志 $b$
}

\section{Quantitation of Cellular Phosphorylation Dynamics by Phosphoproteomics Approaches}

\author{
Yasushi Ishihama*,a and Koshi Imami ${ }^{b}$ \\ ${ }^{a}$ Graduate School of Pharmaceutical Sciences, Kyoto University; 46-29 Yoshidashimoadachi-cho, \\ Sakyo-ku, Kyoto 606-8501, Japan: and bepartment of Biochemistry and Molecular \\ Biology, University of British Columbia; Vancouver, BC, V6T 1Z4, Canada.
}

(Received November 9, 2013)

\begin{abstract}
Reversible phosphorylation of proteins controlled by kinases and phosphatases is one of the most ubiquitous posttranslational modifications, and regulates a variety of cell functions through cellular signal transduction pathways. These signals are involved in various diseases such as cancer and rheumatism, and often cause the disease itself or drive the progression. Quantitative phosphoproteomics based on liquid chromatography-tandem mass spectrometry combined with phosphopeptide enrichment and stable isotope labeling allows profiling thousands of phosphorylation sites on human proteins and has been applied to monitoring cellular phosphorylation dynamics induced by various growth factors, hormones and other perturbations including kinase inhibitors. Here, we employed these technologies to quantify the temporal response of phosphorylation dynamics in SKBR3 breast cancer cells to lapatinib, a kinase inhibitor for epidermal growth factor receptor (EGFR) and EGFR2 (also known as HER2). Among 4953 identified phosphopeptides from 1548 proteins, a small proportion (5-7\%) was regulated at least twofold by $1-10 \mu \mathrm{M}$ lapatinib. The results provide new insights into EGFR/HER2 regulation through region-specific phosphorylation, as well as a global view of the cellular signaling networks associated with the anti-breast cancer action of lapatinib.
\end{abstract}

Key words — phosphoproteomics; molecular-targeting drug; kinase inhibitor; hydroxy acid-modified metal oxide chromatography; mass spectrometry

\section{1. はじめに}

タンパク質の可逆的リン酸化修飾反応は, 様々な 細胞内シグナル伝達経路のほぼすべてに係わってお り，細胞機能を幅広く制御している．このリン酸化 修飾反応の責任酵素であるプロテインキナーゼは, ヒトゲノム中で約 $2 \%$ を占めており, 最大のファミ リーの 1 つである.コード遺伝子は 518 種あると予 測されており，80\%強がセリン/スレオニンキナー ゼで残りがチロシンキナーゼである. UniProt（www. uniprot.org) 中の Swiss-Prot Protein Knowledgebase では，現在ヒトプロテインキナーゼと注䣋づけされ

The authors declare no conflict of interest.

$a$ 京都大学大学院薬学研究科（于606-8501 京都市左京 区吉田下阿達町 46-29), ${ }^{b}$ Department of Biochemistry and Molecular Biology, University of British Columbia (Vancouver, BC, V6T 1Z4, Canada)

*e-mail: yishiham@pharm.kyoto-u.ac.jp

本総説は, 日本薬学会第 133 年会シンポジウム S29101 で発表した内容を中心に記述したものである.
ているタンパク質は 483 種となっている．このリン 酸化修飾は, 増殖, 細胞分裂, 代謝, 分化, オルガ ネラ輸送, 筋肉収縮, 細胞接着, 記憶, 情動等々, ありとあらゆる様々な細胞機能や生命機能調節に係 わっており, 最もユビキタスな翻訳後修飾である. リン酸化修飾がプロテオミクスの手法で解析され始 める以前は, リン酸化タンパク質数は全ヒトタンパ ク質の $30 \%$ 程度であると推測されていた。 ${ }^{1)} し か$ し, リン酸化プロテオミクス（後述）の手法が取り 入れられて以降，リン酸化タンパク質数は驚異的な 数で増加しており, 例えばわれわれの網羅的測定の 結果では, 14627 ヒトタンパク質がリン酸化修飾を うけており，部位数としては，111000を超えるこ とが分かってきた（Fig. 1).すなわち，1つのキ ナーゼは平均 200 以上のリン酸化部位を修飾してい ることになる.

さて，がんやリューマチなどでは，発症・進行の 直接原因は特定のシグナル伝達経路の異常な活性化 


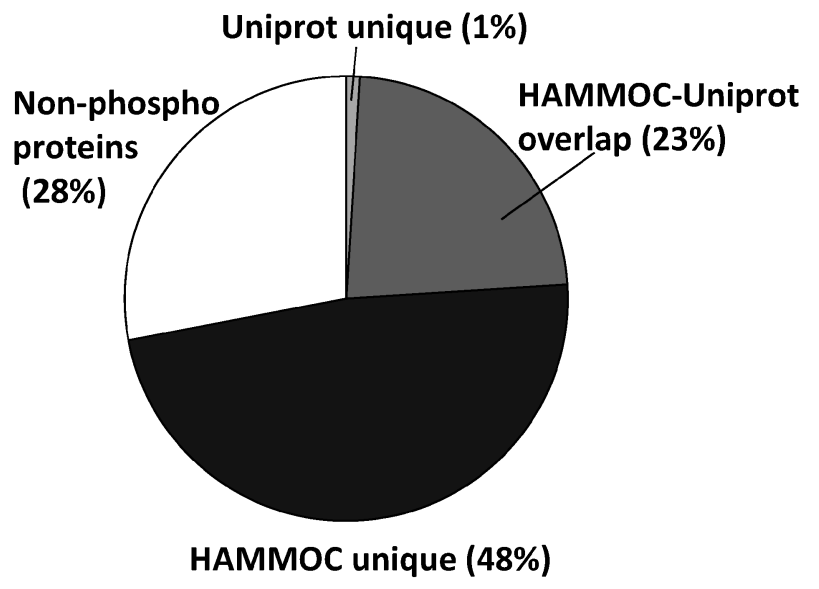

Fig. 1. Identification of Human Phosphoproteins by HAMMOC-based Phosphoproteomics and Uniprot

More than $70 \%$ of human proteins are modified with phosphorylation.

であるとされており，例えば抗がん剂の分野ではが ん特異的なキナーゼをターゲットとした分子標的創 薬・治療が注目されている。代表的な分子標的薬で あるイマチニブの画期的な成功以降，世界規模でが ん分子標的薬の開発が行われ，現在では 20 を超え るがん分子標的治療薬が承認されている。さらに 80 種程度の低分子化合物がキナーゼを標的とする

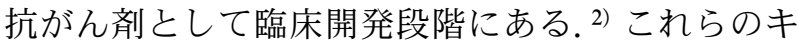
ナーゼ阻害薬については，キナーゼ間で類似性の高 いATP 結合サイトに対する阻害を作用機序とする ことが多いので，単一のキナーゼのみを分子標的と することは難しいが，臨床上はむしろ複数標的に対 する“マルチターゲット”作用薬の方が優れた成績 を上げることも多い. ${ }^{3)}$ これはがん細胞内シグナル 伝達ネットワークが非常に複雑であり，かつ個別の 細胞によって異なる活性化プロファイルを示すから である．すなわち阻害薬の効果をみるにあたって は，ある特定の分子や経路の変動だけではなく，で きるだけ多くの経路への影響をみる必要がある。し かしマルチキナーゼ阻害薬の複雑な作用機序を完全 に明らかにすることは容易ではなく，特に開発早期 段階では詳細な作用機序は解明されていないことも 多い，細胞内シグナル伝達ネットワーク全体を定量 的に，しかもハイスループットに俯瞰できる方法の 確立が強く求められている.

安定同位体標識-液体クロマトグラフィーータンデ ム質量分析（LC-MS/MS）による定量ショットガ ンプロテオミクスとリン酸化ペプチド濃縮法を組み
合わせた定量リン酸化プロテオミクス手法は，シグ ナル伝達ネットワークの全体像を俯瞰するのに最も 強力なアプローチの 1 つである。本稿では，近年技 術の進展が著しいリン酸化プロテオミクス手法を用 いた大規模な細胞内リン酸化動態定量と分子標的薬 評価への応用について，われわれの研究を中心に紹 介する。

\section{2. 定量リン酸化プロテオミクスの開発}

多くの細胞内シグナル伝達経路は細胞膜受容体か ら転写因子へのリン酸基のリレーによって制御され ている，キナーゼはリン酸基転移酵素であり，また キナーゼ自身もリン酸化により活性化される。した がって，キナーゼ触媒部位のリン酸化状態を測定す ることで，キナーゼ活性をプロファイルすることが できる，例えば，Bantscheff らはキナーゼ阻害薬を 樹脂表面に固定した担体を用いて，1 回の LC-MS/ MS 測定で約 180 種のヒト細胞中のキナーゼを同定

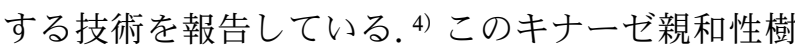
脂とリン酸化ペプチド濃縮法（後述）を組み合わせ ることで，イマチニブ処理細胞における BCR-ABL やその下流のキナーゼのリン酸化プロファイリング に成功している。しかし，この種のアッセイはキ ナーゼのみに着目しているため, 薬剤のシグナル伝 達ネットワークレベルでの影響を評価するには不向 きである．定量リン酸化プロテオミクスは，選択的 リン酸化ペプチド濃縮法，安定同位体標識法及び LC-MS/MS の組み合わせで構成されており，現在 では単独の細胞種から 1-3 万のリン酸化部位を同 定・定量することが可能となってきている. ${ }^{5-7)}$ 特 に，選択的リン酸化ペプチド濃縮法として，固定化 金属イオンアフィニティークロマトグラフィー (immobilized metal ion affinity chromatography; IMAC) ${ }^{8)}$ や，チタニア $\left(\mathrm{TiO}_{2}\right)$ などを用いた酸化金属クロ マトグラフィー (metal oxide affinity chromatography；MOAC) ${ }^{9-11)}$ を用いたシステムでは，比較的配 列依存性なくセリン/スレオニン/チロシンリン酸化 ペプチドを偏りなく同定することができるため，リ ン酸化プロテオミクスで汎用されている.

Figure 2 にリン酸化プロテオーム解析の一般的な 流れを示す。試料から抽出したタンパク質をトリプ シンなどの消化酵素で断片化処理した後，リン酸化 ペプチド濃縮を行い， LC-MS/MS 測定を行う. IMAC 法では，主に $\mathrm{Fe}^{3+}, \mathrm{Ga}^{3+}, \mathrm{Ti}^{4+}$ といつた金 


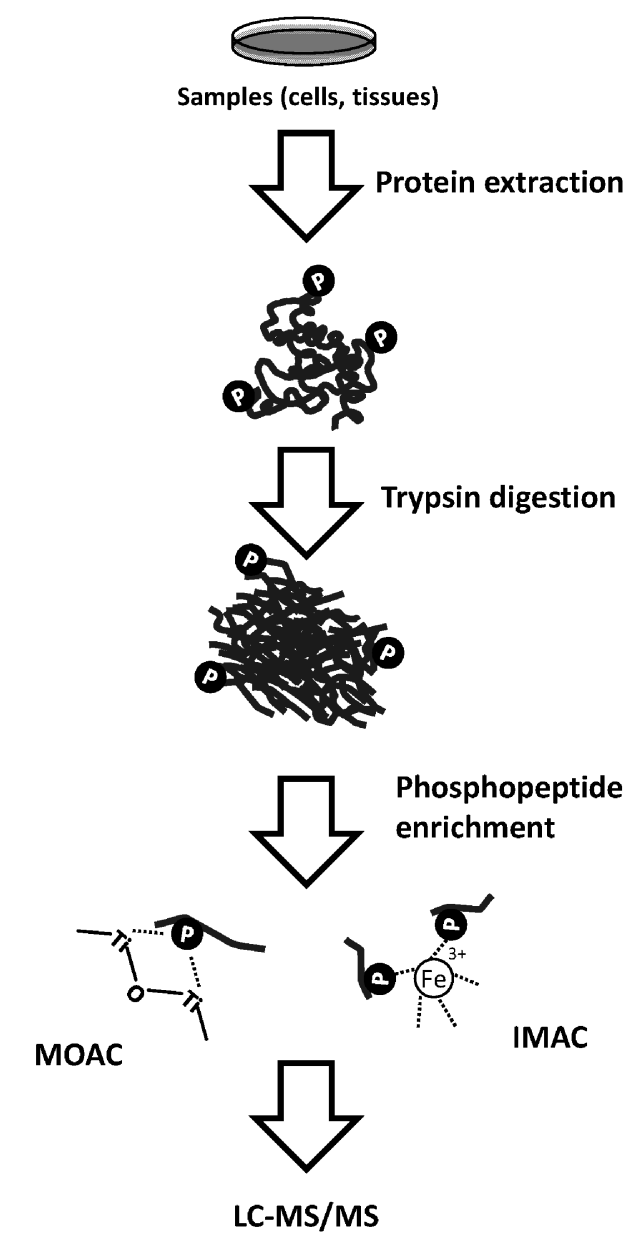

Fig. 2. Workflow of Phosphoproteomics

属イオンが用いられる。IMACにおいて, 非リン 酸化酸性ペプチドの金属イオンへの結合は，リン酸 化ペプチドの同定数を著しく減少させる. したがつ て，カルボキシル基をエステル化したり，12）試料溶 液中の $\mathrm{pH}$ を最適化したりするなど, ${ }^{13)}$ リン酸化ぺ プチドと酸性ペプチドの電荷をうまくコントロール することで, リン酸化ペプチドに対する選択性を向 上させている. 一方, MOAC ではチタニア $\left(\mathrm{TiO}_{2}\right)$, ジルコニア $\left(\mathrm{ZrO}_{2}\right)$ ，アルミナ等が用いられる.

IMAC と同様, 酸性ぺプチドの酸化金属への吸着 が問題となるが，当初は 2,5-ジヒドロキシ安息香酸 やフタル酸などの芳香族酸性化合物が競合剂として

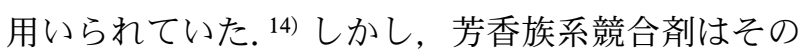
後の LC-MS 測定を妨害し, また濃縮における選択 性向上効果も不十分であることから，われわれは様 々な親水性化合物をスクリーニングした結果, チ夕 ニアに対して乳酸を競合剂として用いることによ り，リン酸化ペプチドに対する選択性・回収率が劇

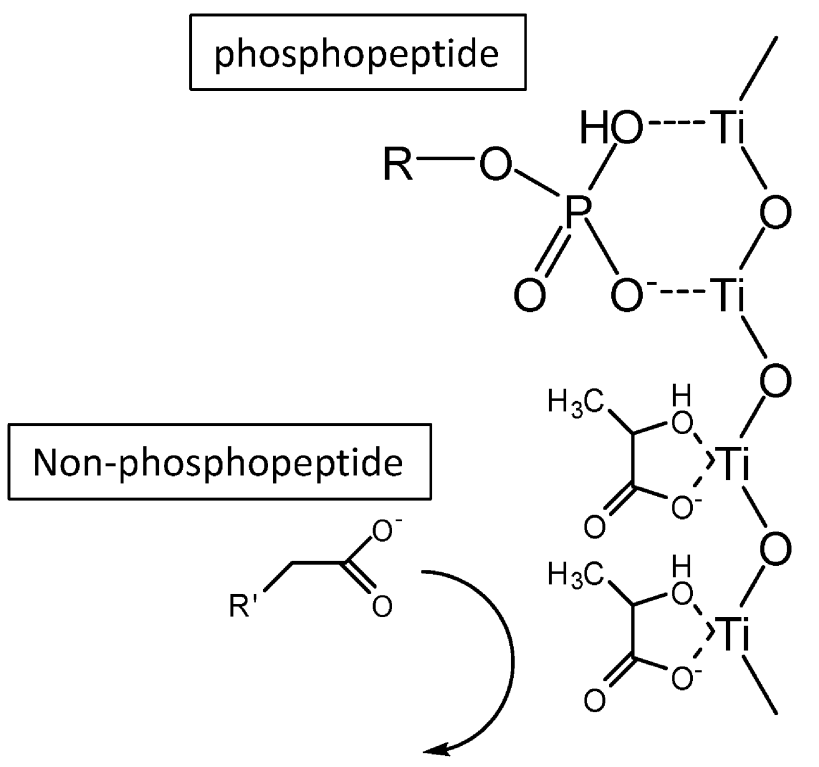

Fig. 3. Principle of HAMMOC Approach

Phosphopeptides are captured while acidic non-phosphopeptides are excluded in the presence of lactic acid on titania beads.

的に向上することを見い出した (Fig. 3).15)この aliphatic hydroxy acid-modified metal oxide chromatography（HAMMOC）法を用いることにより， 世界で初めて細胞抽出物から前分画なしに直接数千 個のリン酸化ペプチドを同定することに成功した. その後の濃縮条件等の最適化により, 回収率, 選択 性はさらに向上し，現在は $100 \mu \mathrm{g}$ の細胞抽出タン パク質から 2-3 回の LC-MS 測定で 5000-14000 個 程度のユニークなリン酸化ペプチドが同定可能とな っている。

一方，リン酸化プロテオームをプロファイルする ためには定性情報だけでは不十分で，その定量は不 可欠である. リン酸化プロテオームの定量法として はプロテオミクスで主に利用されている安定同位 体標識法を用いることができる. Stable isotope labeling using amino acid in cell culture (SILAC) 法は 細胞培養時に安定同位体標識を行うため, 実験誤差 を最小限にすることが可能であるが，リン酸化ペプ チド定量の際には特に注意が必要である。すなわ ち, 安定同位体標識アルギニンを用いて細胞を培養 した場合，アルギニンは生体内で代謝的にプロリン に変換されるため, プロリン含有ペプチドに対して は安定同位体標識プロリンを含むぺプチドと未標識 のプロリンを含むぺプチドに由来する 2 つのピーク

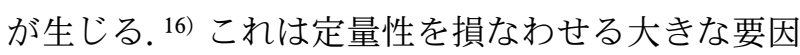


であり，特にリン酸化部位周辺にはプロリンが含ま れることが多いため, リン酸化プロテオーム解析に おいてはその影響が顕著にあらわれる。また， SILAC 法では安定同位体アミノ酸で完全にタンパ ク質を標識するために透析血清の使用が必須であ る. しかし通常血清培地から透析血清培地に変更す ることで細胞の状態（プロテオーム・リン酸化プロ テオームの発現プロファイル等）や増殖速度を変化 させてしまう. ${ }^{17)}$ そこで透析血清使用に伴う問題及 び上述のプロリン変換問題を回避するために，われ われは二重標識 SILAC 法を開発した。 ${ }^{17)}$ 従来 SILAC 法と異なる点は，比較したい 2 つの細胞群 に対して 2 種類の安定同位体標識アミノ酸（アルギ ニン，リシンに対して各 2 種類）で両細胞とも標識 し，通常血清を用いて培養する点である（Fig. 4). 当然，非標識ペプチドも検出されるが，質量スペク トル中で標識ペプチドに由来する 2 つのピークにの み着目し比較することで，通常血清条件下での定量 が可能となる，さらに，両細胞とも安定同位体標識 アルギニンを用いて培養しているため，両者とも同

\section{SILAC with non-dialyzed serum}

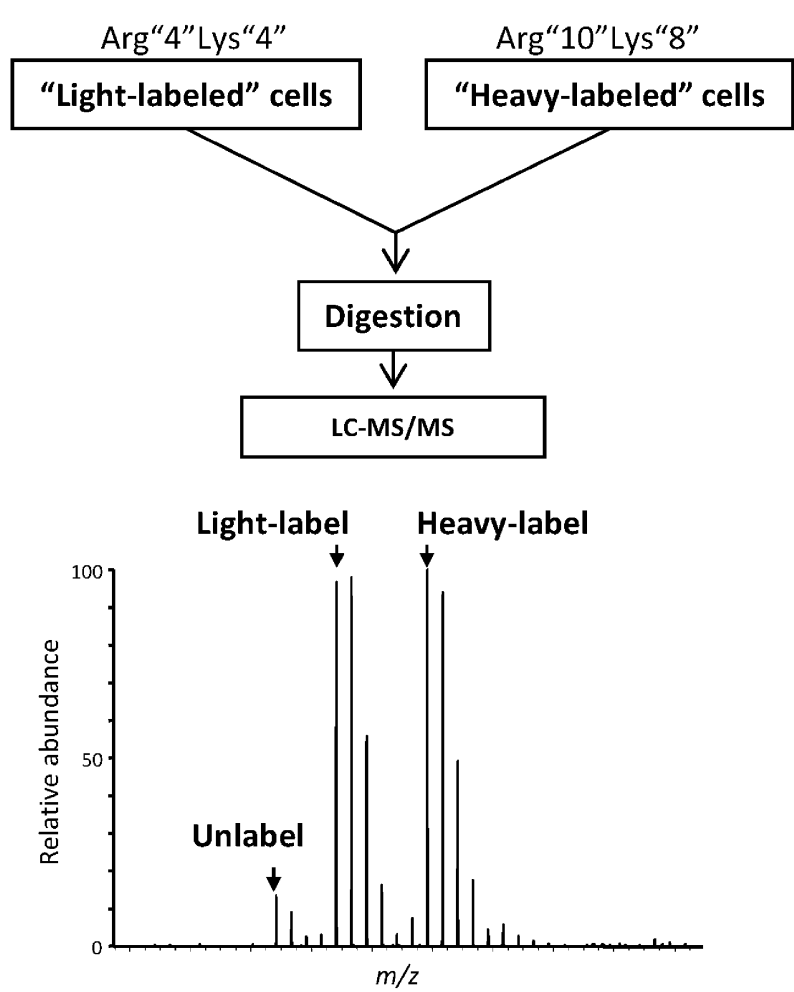

Fig. 4. Double-labeled SILAC Approach with Non-dialyzed Serum
じ割合で安定同位体標識アルギニンのプロリン変換 が進行することになる。したがって，2つの標識ぺ プチドのモノアイソトープピークに着目し，それら の相対比を定量することでプロリン変換の影響を除 くことが可能となる.

3. リン酸化プロテオミクスを用いたリン酸化動 態定量と分子標的薬評価

分子標的薬評価に定量的リン酸化プロテオミクス を用いたという報告は今までにもいくつか発表され ているが，すべて特定の薬剤濃度・処理時間におけ るリン酸化状態の定量に限られていた。最近われわ れは乳がん治療薬ラパチニブを用い，その薬剤濃度 及び 1 時間以内の処理時間依存的なリン酸化シグナ ル動態の計測について報告した. ${ }^{18)}$ ラパチニブの直 接の標的分子は EGFR1 及び EGFR2（HER2）で あり，その他のキナーゼにはほぼ阻害活性を示さな い. EGFR1/2 が発現している乳がん細胞 SKBR3 を用い，二重標識 SILAC 法と HAMMOC 法によ つて， $1,5,10$ 及び 60 分間ラパチニブで処理した 乳がん細胞のリン酸化プロテオーム（4953 リン酸 化ペプチド，1548 リン酸化タンパク）を時系列に 沿ってプロファイルした（Fig. 5)。その結果，全 体の 5-7\%に相当するリン酸化ペプチドが 2 倍以上 変化し，薬剂標的分子 EGFR やその下流の因子 （ERK キナーゼ，転写因子 JUN など）のリン酸化 が濃度及び時間依存的に抑制される過程を捉えるこ とができ，ラパチニブのシグナル伝達ネットワーク レベルでの作用機構の全体像を明らかにした。ま た, 個々の分子に注目し, EGFR2 のリン酸化ダイナ ミクスデータからラパチニブ処理によって EGFR2 の 1050 番台のセリン/スレオニンのリン酸化が充進 することを見い出した。そこで，この責任キナー ゼ同定のため, Human Protein Reference Database $(H P R D)^{19)}$ に登録されているリン酸化モチーフとそ れに対応するキナーゼペア情報から，候補キナーゼ を数種抽出した，EGFR2 の特定領域をカバーする ペプチドを合成し，候補キナーゼと in vitro アッセ イを行い, PKA, PKC, CAMKII を第 2 次候補とし て選別した。この中で PKAについては，その活性 化状態の指標となるリン酸化部位がラパチニブ処理 により六進しており，さらにラパチニブと PKA 阻 害薬（H89）で処理した細胞では EGFR2 の特定領 域のリン酸化のみならずチロシンキナーゼ活性が抑 


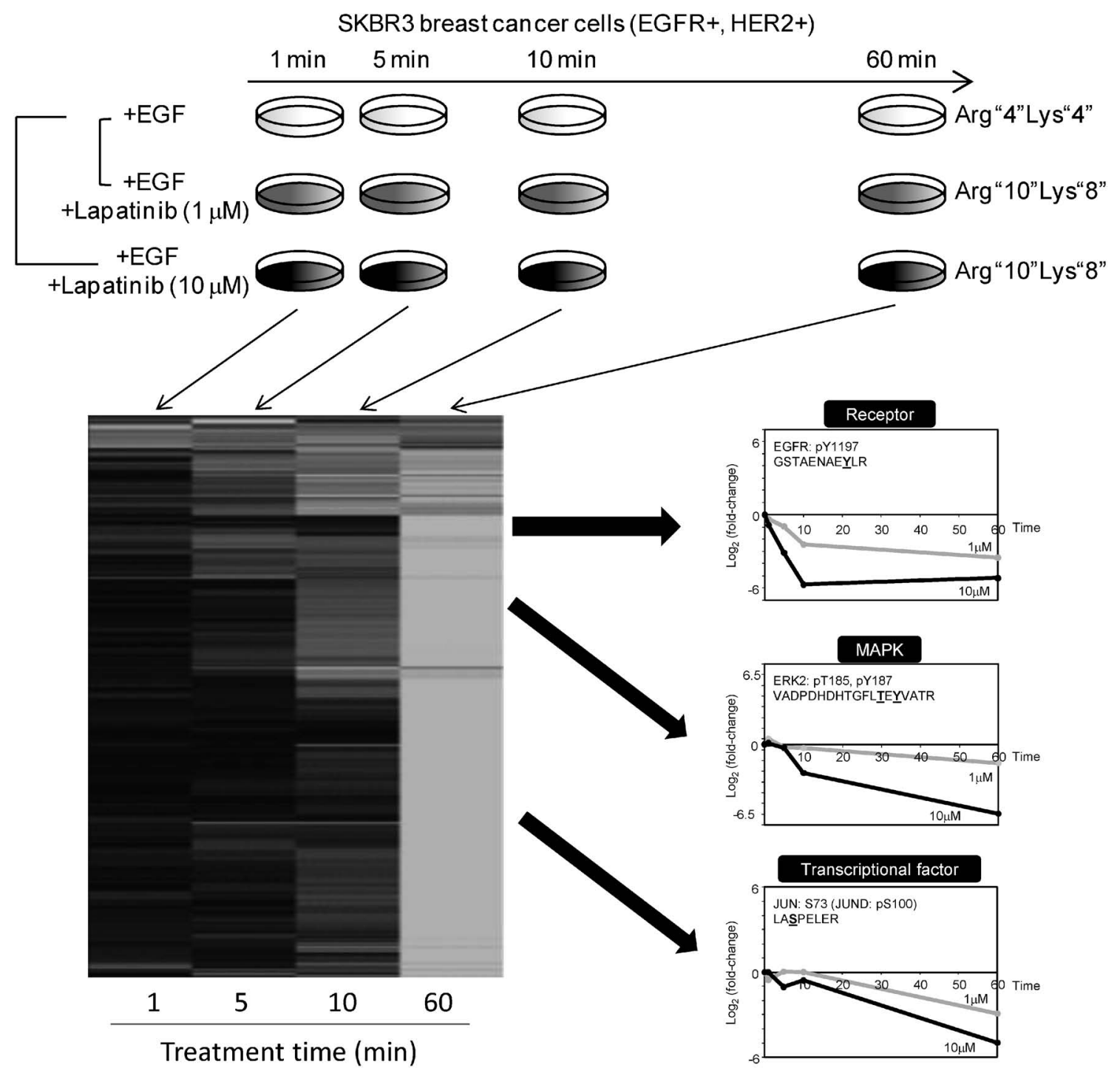

Fig. 5. Quantitation of Lapatinib-induced Phosphorylation Dynamics by HAMMOC-based Phosphoproteomics with Double-labeled SILAC

制されることを確認した。 すなわち，われわれが今 回新規に同定した EGFR2 のセリン/スレオニンリ ン酸化部位は，PKAによってリン酸化され，それ によりチロシンキナーゼ活性が充進することが見い 出された。実際の臨床検体でこれらのリン酸化が観 測され，ラパチニブ而性との相関があるかどうかが 次の課題である.

次に，ラパチニブのシグナル伝達ネットワークレ ベルでの全体像を明らかにすべく，タンパク質間相 互作用ネットワークデータベース STRING ${ }^{20)}$ を用 い，既知ネットワーク上に，リン酸化が 2 倍以上変 動した 210 個のタンパク質をマップした. その結果,

EGFR $1 / 2$ シグナル経路に係わる分子群のみなら ず，これまで EGFR $1 / 2$ 経路との関連が示されてい
なかった転写・翻訳に係わる一連の分子群にもラパ チニブの影響が認められた。 ラパチニブの EGFR1 $/ 2$ への高選択的阻害活性を考えると，これらの分 子群は EGFR1/2 の下流に存在し，なんらかの細胞 機能制御に係わっているものと考えられる.

以上，ラパチニブを例に，定量リン酸化プロテオ ミクスを用いた分子標的薬動態評価について紹介し た．誌面の都合で割愛したが，リン酸化動態プロフ アイルの相似性を利用した解析も行っており，単に 測定するだけでなく，その後の解析を独自に工夫す ることにより，まだまだ多くの情報を抽出できるも のを考える. Database for Annotation, Visualization and Integrated Discovery (DAVID) ${ }^{21)}$ や STR$\mathrm{ING}^{20)}$ といつた公共バイオインフォマティクス 
ツール（データベース）の環境が整ってきており, この分野の今後の発展が期待できる. しかし, リン 酸化ネットワークの大部分は未知であり, 特に細胞 内の生理的条件下におけるキナーゼ-基質ペア情報 を大規模に取得することは現在の技術ではまだ難し く, これからの研究に期待したい.

\section{4. おわりに}

質量分析の急速な技術発展とその周辺技術の成熟 により，プロテオミクスに関する技術開発は目覚ま しい勢いで進行している。リン酸化修飾だけでな く，その他の翻訳後修飾についても大規模解析法の 開発がますます加速すると思われる，定量プロテオ ミクスの手法は実験動物にも応用されており，今後 培養細胞レベルではなく個体レベルでのリン酸化プ ロファイルもより加速していくだろう。一方，リン 酸化プロテオミクスで取得できる情報は複数の細胞 から生じるリン酸化反応の平均挙動であり，例えば がん幹細胞とその周辺のがん細胞における単一細胞 レベルでの挙動を定量するのは困難である．現時点 でのリン酸化プロテオミクスの最高感度はわれわれ が報告した 10000 細胞でのプロファイルであり, 22) 更なる感度向上にむけた技術開発ブレークスルーが 必須である。最近，マスサイトメトリーと同位体夕 グを複数組み合わせたバーコード質量技術を組み合 わせることで，単一種の細胞レベルで数百のパラ メーター（リン酸化状態，マーカータンパク質の発 現量等）のハイスループット定量も報告されてい る. ${ }^{23-25)}$ リン酸化プロテオミクスは，個別化医療を 実現するためのツールとしても大いに期待できる.

\section{REFERENCES}

1) Cohen P., Trends Biochem. Sci., 25, 596-601 (2000).

2) Zhang J., Yang P. L., Gray N. S., Nat. Rev. Cancer, 9, 28-39 (2009).

3) Apsel B., Blair J. A., Gonzalez B., Nazif T. M., Feldman M. E., Aizenstein B., Hoffman R., Williams R. L., Shokat K. M., Knight Z. A., Nat. Chem. Biol., 4, 691-699 (2008).

4) Bantscheff M., Eberhard D., Abraham Y., Bastuck S., Boesche M., Hobson S., Mathieson T., Perrin J., Raida M., Rau C., Reader V., Sweetman G., Bauer A., Bouwmeester T., Hopf C., Kruse U., Neubauer G., Ramsden
N., Rick J., Kuster B., Drewes G., Nat. Biotechnol., 25, 1035-1044 (2007).

5) Olsen J. V., Vermeulen M., Santamaria A., Kumar C., Miller M. L., Jensen L. J., Gnad F., Cox J., Jensen T. S., Nigg E. A., Brunak S., Mann M., Sci. Signal., 3, ra3 (2010).

6) Rigbolt K.T., Prokhorova T. A., Akimov V., Henningsen J., Johansen P. T., Kratchmarova I., Kassem M., Mann M., Olsen J. V., Blagoev B., Sci. Signal., 4, rs3 (2011).

7) Beli P., Lukashchuk N., Wagner S. A., Weinert B. T., Olsen J. V., Baskcomb L., Mann M., Jackson S. P., Choudhary C., Mol. Cell, 46, 212-225 (2012).

8) Stensballe A., Andersen S., Jensen O. N., Proteomics, 1, 207-222 (2001).

9) Sano A., Nakamura H., Anal. Sci., 20, 861864 (2004).

10) Kweon H. K., Hakansson K., Anal. Chem., 78, 1743-1749 (2006).

11) Wolschin F., Wienkoop S., Weckwerth W., Proteomics, 5, 4389-4397 (2005).

12) Ficarro S. B., McCleland M. L., Stukenberg P. T., Burke D. J., Ross M. M., Shabanowitz J., Hunt D. F., White F. M., Nat. Biotechnol., 20, 301-305 (2002).

13) Kokubu M., Ishihama Y., Sato T., Nagasu T., Oda Y., Anal. Chem., 77, 5144-5154 (2005).

14) Larsen M. R., Thingholm T. E., Jensen O. N., Roepstorff P., Jørgensen T. J., Mol. Cell. Proteomics, 4, 873-886 (2005).

15) Sugiyama N., Masuda T., Shinoda K., Nakamura A., Tomita M., Ishihama Y., Mol. Cell. Proteomics, 6, 1103-1109 (2007).

16) Van Hoof D., Pinkse M. W., Oostwaard D. W., Mummery C. L., Heck A. J., Krijgsveld J., Nat. Methods, 4, 677-678 (2007).

17) Imami K., Sugiyama N., Tomita M., Ishihama Y., Mol. Biosyst., 6, 594-602 (2010).

18) Imami K., Sugiyama N., Imamura H., Wakabayashi M., Tomita M., Taniguchi M., Ueno T., Toi M., Ishihama Y., Mol. Cell. Proteomics, 11, 1741-1757 (2012).

19) Keshava Prasad T. S., Goel R., Kandasamy K., Keerthikumar S., Kumar S., Mathivanan S., Telikicherla D., Raju R., Shafreen B., Venugopal A., Balakrishnan L., Marimuthu A., Banerjee S., Somanathan D. S., Sebastian A., Rani S., Ray S., Harrys Kishore C. J., 
Kanth S., Ahmed M., Kashyap M. K., Mohmood R., Ramachandra Y. L., Krishna V., Rahiman B. A., Mohan S., Ranganathan P., Ramabadran S., Chaerkady R., Pandey A., Nucleic Acids Res., 37 (Suppl. 1) , D767-D772 (2009).

20) Franceschini A., Szklarczyk D., Frankild S., Kuhn M., Simonovic M., Roth A., Lin J., Minguez P., Bork P., von Mering C., Jensen J. L., Nucleic Acids Res., 41 (D1), D808D815 (2013).

21) Huang da W., Sherman B. T., Lempicki R. A., Nat. Protoc., 4, 44-57 (2009).

22) Masuda T., Sugiyama N., Tomita M., Ishihama Y., Anal. Chem., 83, 7698-7703 (2011).
23) Bodenmiller B., Zunder E. R., Finck R., Chen T. J., Savig E. S., Bruggner R. V., Simonds E. F., Bendall S. C., Sachs K., Krutzik P. O., Nolan G. P., Nat. Biotechnol., 30, 858-867 (2012).

24) Bendall S. C., Simonds E. F., Qiu P., Amir elA. D., Krutzik P. O., Finck R., Bruggner R. V., Melamed R., Trejo A., Ornatsky O. I., Balderas R. S., Plevritis S. K., Sachs K., Pe'er D., Tanner S. D., Nolan G. P., Science, 332, 687-696 (2011).

25) Bandura D. R., Baranov V. I., Ornatsky O. I., Antonov A., Kinach R., Lou X., Pavlov S., Vorobiev S., Dick J. E., Tanner S. D., Anal. Chem., 81, 6813-6822 (2009). 